\title{
The Use of Trade-Off Analysis in Analyzing the Implementation of New Students' Admissions Selection Policy in Bandung State Middle School
}

\author{
Rita Anggorowati \\ Educational Department \\ School of Post Graduates UPI \\ Bandung, Indonesia \\ ritalope11@student.upi.edu \\ Eka Prihatin \\ Educational Department \\ School of Post Graduates UPI \\ Bandung, Indonesia
}

\begin{abstract}
The admission process of the prospective students who wish to continue their studies to the next level in the public school called the New Students Admissions Selection. The selection process is carrying the standard criteria that must be met by all prospective students. Selection is carried out based on the regulations set forth in Bandung Mayor Regulation No. 361 in 2015 and No. 610 in 2016. The chaotic implementation of the process in Bandung occurred. It was in the academic year of 2015/2016; in which there was an imbalance of the number of prospective new students which exceed the capacity public schools. This fact was becoming the background of the research. The research approach used was qualitative descriptive case study method, took place in Bandung using purposively sampling. The research instruments used were interviews, the existing documents on the subject matters, focus group discussions and questionnaires. The process of data analysis was using the Trade-off analysis. The results showed that the policy implementation was facing some obstacles, especially at the technical level such as public trials, socialization, improper substance regulations and new policy within the policy.

Keywords-Policy Analysis, Policy Implementation, New
\end{abstract} Students Admissions Selection

\section{INTRODUCTION}

The admission process of prospective students who wish to continue study from elementary school to junior high and from Junior High School to Senior High School in Bandung was called as the New Students Admissions Selection (PPDB). The selection process is carrying the standard criteria that must be met by all prospective students. In the eyes of education, PPDB selection is basically a competition. Where in the process and the outcome, there will be students who successfully accepted in public schools funded by the government and some who are not.

This condition is contradictive with [1] which stated that every citizen has the same rights to acquire quality education, started from aged seven to fifteen years has the same rights to get the compulsory basic education. This includes the regulation that Government and Local

\author{
Aan Komariah \\ Educational Department \\ School of Post Graduates UPI \\ Bandung, Indonesia
}

Government are required to provide services and facilities, and ensure the quality education for every citizen without discrimination. Furthermore, they must ensure the availability of funds for implementation of education for every citizen aged seven to fifteen years.

The above verse and chapter in general focuses on students' rights as citizens to obtain the same educational services, without distinguishing the registration lines; be it academic, non-academic, Certificate of Disadvantaged (SKTM), and others. Similarly, the role of government and local governments in providing services and facilities, and ensure the quality education for every citizen without any discrimination.

\section{RESEARCH METHODOLOGY}

The research approach used was qualitative descriptive case study method, took place in Bandung using purposively sampling. The population and sample were taken from the representatives of the Government Public Servant in Bandung Regency, the representatives of Bandung Regional Ministry of Education Office, school principals, teachers, school committee, parents, students and Bandung Independent PPDB Observer Community. The research instruments used were interviews, the existing documents on the subject matters, focus group discussions and questionnaires. The process of data analysis was using the Trade-off analysis.

Table 1 below was describing the concept of operationalization used in this research: 
Table 1. Concept Of Operationalization

\begin{tabular}{|c|c|c|c|}
\hline Category & Sub Category & Indicators & Unit \\
\hline $\begin{array}{c}\text { Policy } \\
\text { Implementation }\end{array}$ & $\begin{array}{l}\text { 1. Socialization } \\
\text { 2. Understanding } \\
\text { 3. Communication } \\
\text { 4. Obstacles } \\
\text { 5. Government } \\
\text { Role }\end{array}$ & 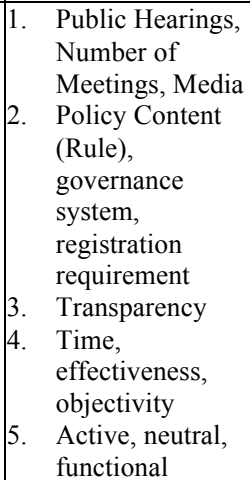 & $\begin{array}{l}\text { Good, } \\
\text { Fair, } \\
\text { Poor }\end{array}$ \\
\hline
\end{tabular}

Data collection matrix conducted by researcher based on the operational concept of the foregoing were presented in Table 2 as follows:

Table 2 Data Collection Matrix

\begin{tabular}{|c|c|c|c|c|}
\hline \multirow[t]{2}{*}{ Aim } & \multicolumn{3}{|c|}{ Primarily Data } & \multirow{2}{*}{$\begin{array}{c}\text { Secondary } \\
\text { Data }\end{array}$} \\
\hline & $\begin{array}{l}\text { In-depth } \\
\text { Interview }\end{array}$ & Observation & Survey & \\
\hline $\begin{array}{l}\text { Finding } \\
\text { data in } \\
\text { regards to } \\
\text { the } \\
\text { implementa } \\
\text { tion of the } \\
\text { policy }\end{array}$ & $\begin{array}{l}\text { Tools: } \\
\text { Interview } \\
\text { guidelines } \\
\text { Substance: } \\
\text { All } \\
\text { information } \\
\text { related to the } \\
\text { PPDB policy } \\
\text { implementati } \\
\text { on in } \\
\text { Bandung. } \\
\text { Informants: } \\
\text { Figures } \\
\text { representing } \\
\text { the local } \\
\text { government } \\
\text { of Bandung } \\
\text { (policymaker } \\
\text { s team, the } \\
\text { head of } \\
\text { department } \\
\text { units and } \\
\text { supervisors } \\
\text { in Bandung } \\
\text { Regional } \\
\text { Ministry of } \\
\text { Education), } \\
\text { those who } \\
\text { represents } \\
\text { the executive } \\
\text { committee of } \\
\text { PPDB } \\
\text { (principals) } \\
\text { and other } \\
\text { relevant } \\
\text { informants. } \\
\text { Informant } \\
\text { Selection: } \\
\text { Purposive } \\
\text { and } \\
\text { snowball. }\end{array}$ & $\begin{array}{l}\text { During } \\
\text { interview and } \\
\text { Focus Group } \\
\text { Discussion }\end{array}$ & $\begin{array}{l}\text { Tools: } \\
\text { Questionnair } \\
\text { e form } \\
\text { Substance: } \\
\text { Related to } \\
\text { the } \\
\text { perception } \\
\text { and } \\
\text { understandin } \\
\text { g of PPDB } \\
\text { policy } \\
\text { implementati } \\
\text { on in } \\
\text { Bandung. } \\
\text { Sample: } \\
\text { Random } \\
\text { purposive } \\
\text { (presented in } \\
\text { the Google } \\
\text { forms } \\
\text { distributed } \\
\text { randomly } \\
\text { through } \\
\text { social media } \\
\text { for the } \\
\text { executive } \\
\text { committee } \\
\text { and the } \\
\text { parents as } \\
\text { well as } \\
\text { prospective } \\
\text { students who } \\
\text { were } \\
\text { involved at } \\
\text { the time of } \\
\text { PPDB } \\
\text { process. }\end{array}$ & $\begin{array}{l}\text { Substance: } \\
\text { Supporting } \\
\text { data, both in } \\
\text { policy } \\
\text { implementati } \\
\text { on as well as } \\
\text { on the } \\
\text { content of } \\
\text { the PPDB } \\
\text { policy. } \\
\text { Source: } \\
\text { Local press, } \\
\text { blog, data } \\
\text { statistics of } \\
\text { students who } \\
\text { registered in } \\
\text { PPDB, } \\
\text { Private } \\
\text { Schools } \\
\text { Principals' } \\
\text { Focus Group } \\
\text { Discussion. }\end{array}$ \\
\hline
\end{tabular}

The above data collection matrix were made based on data collection procedures proposed by [2], [3] and [4]. By which the researcher conducted a code to identify separate units of information from texts and to write and organize data based on the meaning equation. [5]

Then the exposure data conducted by researcher sought to address all data regarding to the implementation of PPDB 2015 policies and governance systems in Bandung completed with the contents of the policy, governance systems as well as supporting factors and inhibitors that influence the policy of the Government of Bandung in improving the quality of PPDB selection process in the city by using the trade-off analysis method with two activities, namely Stakeholder and Multi Criteria analysis. In the end, the result of the analysis plays the important role on the discussion section.

In conducting primary data collection, researcher conducted in-depth interview to four people representing the Regional Government of Bandung that served as teamwork to policy, decision makers, as well as figures representing the Organizing Committee PPDB selection.

On the primary data questionnaire, there were 33 respondents, who were involved in the selection process of selection of applicants PPDB 2015 as totaling 32 people. Parents involved a number of $46.9 \%, 28.1 \%$ and the number of Education Community Observer process up to $25 \%$.

\section{RESEARCH FINDINGS \& DISCUSSION}

In this study it was discovered that the difference between the learners quota available both in junior high or high school in the city were insignificant; which the junior high school students available quota were 10,239 , while the number of applicants reached 19,227 (1,799 its a registrant who belong to the category outside Bandung, they only have a chance of $10 \%$ of the total registrants in each school). The difference between the number of applicants and the available quota in junior high schools was 8,898 pupils.

While high school students' available quota were 9,273, while the number of applicants reached 12,750; in which the 841 applicants were belongs to outside Bandung category (the provision was similar to the junior level, which only has a chance of $10 \%$ of the total registrants in each school). The difference between the number of applicants and the quota available at the high school level were 3,477 pupils.

The presence of a considerable margin between the high number of prospective new learners applicants and the available quotas in Junior and Senior High School opened the opportunities of the inefficient and dishonest rule set out in the education policy on PPDB governance system.

Reference [6] argued that the level of interests of each stakeholder, both between the public society with the institutions and between institutions of the other institutions require a formulation or measures of public policy analysis to reach a settlement that each stakeholder can be embodied in accordance with interests. She further revealed that the trade-off analysis offered help to get an accommodative 
public policy through a process of public policy analysis accommodative through public policy analysis process involving many different stakeholders with many interests. In the management of these various interests, it should be done wisely and based on think win-win paradigm.

Furthermore, trade-off analysis is the process by which stakeholders involved to consider the benefits of different management strategies, and explicitly define the priority of management. It requires information to be able to answer the questions of stakeholders on the impact of different activities from various sources. The information is then organized, so it would be understandable and useable. This is the main feature of the trade-off analysis. This analysis is a tool that can assist decision makers in understanding the use of sources of conflict and stakeholders' preference in their management process. [7]

Here is a grouping of stakeholders based on the level of interest (importance) and the effect (influence) of the decision-making process:

Figure 1. Stakeholder Categories by Level of Interest and Influence

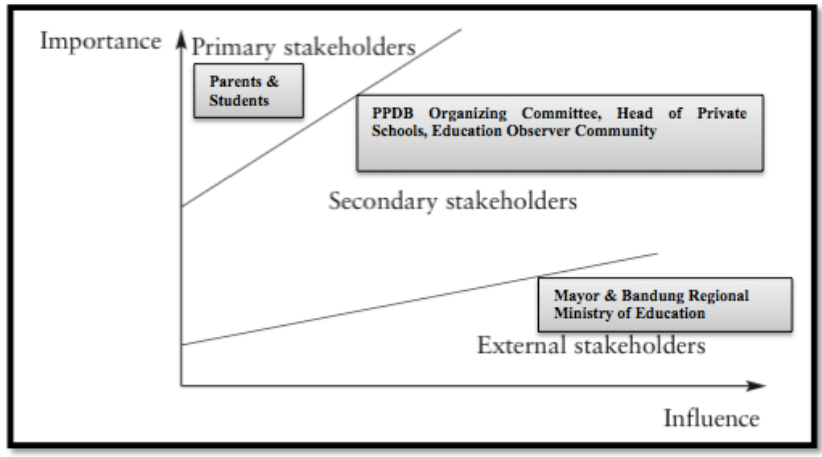

Source: [7]

As described using the quadrant method Power vs. Interest Grid (Figure 2) based on the reference [8], then parents and prospective students were in Subject policy quadrant because they had a high interest, but weak in power. While the main actors, the Mayor, was in Context Setter quadrant, as the stakeholder who had high power with only small direct interest. Bandung Regional Ministry of Education Office, in this case represented by the Head of Department, supervisors and team policy makers are in Player quadrant, as the stakeholders who had power and interest significantly. The last, Education Observer Community and the executive committee of selection were in Crowd quadrant, i.e. stakeholders who were weak in power and interest.
Figure 2. Quadrant Power vs. Interest Grid on PPDB Policy 2015

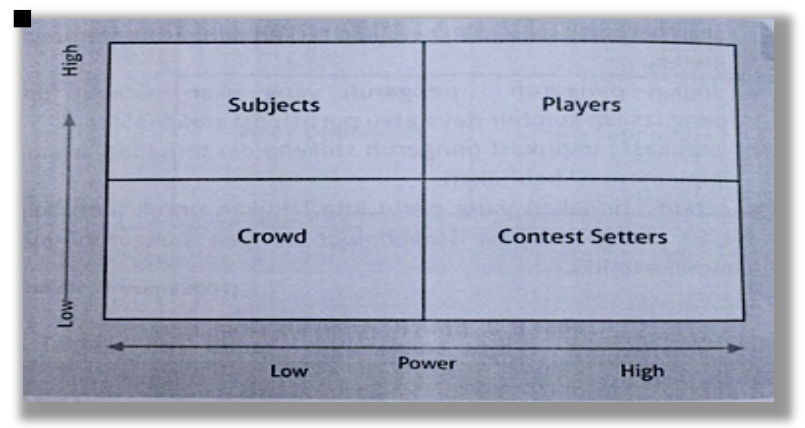

Source: [8]

After mapping the power and interest of each stakeholder, then the researcher determining interventions and measures that need to be made to the stakeholders who have successfully mapped. Picture related interventions to be made to the stakeholders who have known the power as well as its interest could be seen from Figure 3, below:

Figure 3. Actor Type Quadrant in Bandung PPDB Policy

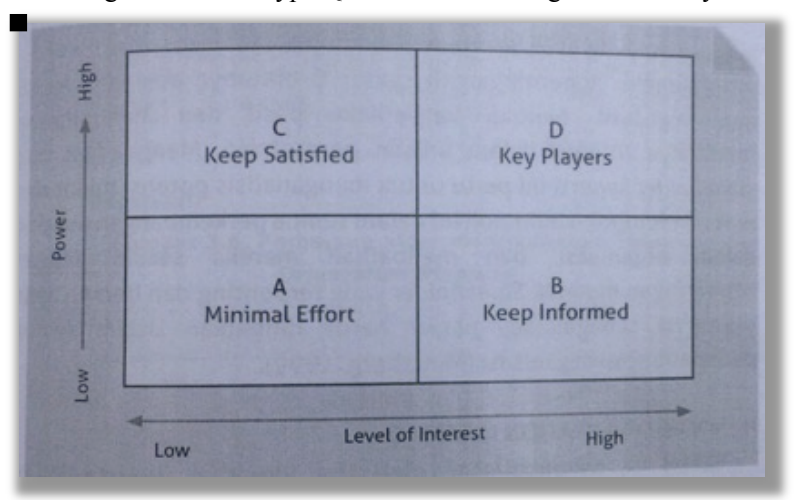

Source: [8]

From Figure 3, it can be seen that the stakeholders in the sector A does not have a high interest in the decision, low power to influence and give great impact. However, this group must be maintained to obtain information within the required limits. The Executive Committee of the Selection PPDB 2015 was in this quadrant.

While stakeholders in the sector B and have a high interest in responding to all the decisions even when they do not have great power to influence. This group can be used as a support on a policy, it is important to inform issues of interest to them. In this study, the position of the parents and prospective students participants PPDB 2015 was the selection of this quadrant.

Stakeholders in the sector C usually were the legislative or public policy observer PPDB. They behave passively and show low interest in matters of policy. Faced with this type of stakeholders such, need to be analyzed potential interest and reactions of each group in each of the developments taking place and involve them in accordance with their interests. Key stakeholders are at D sector, as a key player, they must be involved in all developments. 
The data collected from the stakeholder analysis became the source materials of the multi-criteria analysis. Multi-criteria analysis provides an analytical framework which link the issue of the problems and objectives of management in the future. Stages of the author in applying multi-criteria analysis is as follows:

a. Determining scenario, Criteria and Assessment Impact

Referring to [7], researcher created future scenarios that can explain the impact of the current implementation of PPDB policy; which was being implemented.

Table 3 described the determination of future scenarios for the development of selection PPDB as a policy implementation in Bandung.

Table 3. PPDB Scenario Selection in Bandung

\begin{tabular}{|l|l|}
\hline \multicolumn{2}{|l|}{ Scenario } \\
\hline A & $\begin{array}{l}\text { PPDB Selection conducted Online, short period time of socialization, all SKTM holders } \\
\text { got accepted, school capacity is exceeded }\end{array}$ \\
\hline B & $\begin{array}{l}\text { PPDB Selection conducted Online, socialization period time extended, all SKTM } \\
\text { holders got accepted, school capacity is exceeded }\end{array}$ \\
\hline C & $\begin{array}{l}\text { PPDB Selection conducted Online, socialization period time extended, SKTM holders } \\
\text { were put on the list with full funded by the government. Those who were not accepted in } \\
\text { the public school could be sent to a private school using government funding. Public } \\
\text { school capacity would be in ideal number. }\end{array}$ \\
\hline
\end{tabular}

Multi-criteria analysis required two data inputs: (1) impact matrix and (2) set of weights that accompany the effects of its value. Impact matrix represents the value of the indicator of the expected criteria for each scenario. Indicators to be assessed can be taken from the following sources expert opinion, decision makers and the public obtained from the stakeholder analysis.

After that, the preparation of a choice was ranked by weighting the impact. Ranked by the high weighting of selection will be compared with those of development that are not weighted as input for decision-making.

Assessment of the impact can be obtained from the results of discussions with experts and stakeholders as well as from secondary data. A stakeholder analysis is a system of data collection in various ways to involve stakeholders in the discussion so that they express their choice through interviews, discussions or questionnaires using a participatory approach and presented in Table Impact (The Effects Table) in Table 4.

Table 4. Predicted Impacts of the Policy Scenario

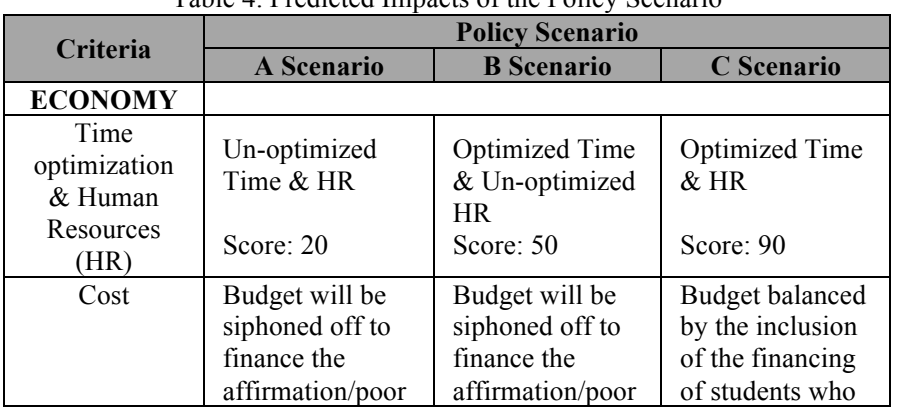

\begin{tabular}{|c|c|c|c|}
\hline \multirow{2}{*}{ Criteria } & \multicolumn{3}{|c|}{ Policy Scenario } \\
\hline & A Scenario & B Scenario & C Scenario \\
\hline & $\begin{array}{l}\text { students } \\
\text { (SKTM) without } \\
\text { being offset by } \\
\text { the influx of } \\
\text { students who } \\
\text { were able to pay } \\
\text { for the school } \\
\text { fees } \\
\text { Score: } 30\end{array}$ & $\begin{array}{l}\text { students } \\
\text { (SKTM) without } \\
\text { being offset by } \\
\text { the influx of } \\
\text { students who } \\
\text { were able to pay } \\
\text { for the school } \\
\text { fees } \\
\text { Score: } 30\end{array}$ & $\begin{array}{l}\text { were able to pay } \\
\text { for the fees and } \\
\text { got accepted in } \\
\text { that particular } \\
\text { public school }\end{array}$ \\
\hline \multicolumn{4}{|l|}{ SOCIAL } \\
\hline $\begin{array}{l}\text { Society needs } \\
\text { to have a } \\
\text { decent } \\
\text { education }\end{array}$ & $\begin{array}{l}\text { Affirmation } \\
\text { students' needs } \\
\text { would be } \\
\text { accommodated, } \\
\text { but the learning } \\
\text { conditions were } \\
\text { not ideal } \\
\text { Score: } 50\end{array}$ & $\begin{array}{l}\text { Affirmation } \\
\text { students' needs } \\
\text { would be } \\
\text { accommodated, } \\
\text { but the learning } \\
\text { conditions were } \\
\text { not ideal }\end{array}$ & $\begin{array}{l}\text { Affirmation } \\
\text { students' need } \\
\text { would be } \\
\text { accommodated } \\
\text { as well as } \\
\text { students who } \\
\text { have good } \\
\text { grades from a } \\
\text { well to do } \\
\text { society } \\
\text { Score: } 85 \\
\end{array}$ \\
\hline $\begin{array}{l}\text { Justice for all } \\
\text { to get a decent } \\
\text { education }\end{array}$ & $\begin{array}{l}\text { As a result of the } \\
\text { buildup of } \\
\text { students from the } \\
\text { path of } \\
\text { affirmation } \\
\text { (SKTM) and } \\
\text { school capacity } \\
\text { is exceeded, then } \\
\text { the purpose of } \\
\text { getting a decent } \\
\text { education would } \\
\text { not be achieved. }\end{array}$ & $\begin{array}{l}\text { As a result of } \\
\text { the buildup of } \\
\text { students from } \\
\text { the path of } \\
\text { affirmation } \\
\text { (SKTM) and } \\
\text { school capacity } \\
\text { is exceeded, } \\
\text { then the purpose } \\
\text { of getting a } \\
\text { decent education } \\
\text { would not be } \\
\text { achieved. }\end{array}$ & $\begin{array}{l}\text { The guarantee } \\
\text { that students } \\
\text { affirmations who } \\
\text { are listed in } \\
\text { Government } \\
\text { Funding, which } \\
\text { stated that in a } \\
\text { case that they } \\
\text { did not pass the } \\
\text { selection are still } \\
\text { eligible to go to } \\
\text { private schools } \\
\text { with full } \\
\text { government } \\
\text { funding will lead } \\
\text { to a condition } \\
\text { where the } \\
\text { capacity of } \\
\text { public schools } \\
\text { are ideal. This } \\
\text { definitely make } \\
\text { justice for the } \\
\text { people to get a } \\
\text { decent education } \\
\text { would be } \\
\text { achieved. } \\
\text { Score: } 90\end{array}$ \\
\hline \multicolumn{4}{|l|}{ POLITICS } \\
\hline $\begin{array}{l}\text { Political } \\
\text { temperature } \\
\text { stability when } \\
\text { the policy } \\
\text { were } \\
\text { implemented }\end{array}$ & $\begin{array}{l}\text { No significant } \\
\text { change in the } \\
\text { political climate } \\
\text { in Bandung, the } \\
\text { situation was } \\
\text { only heated up in } \\
\text { the scope of the } \\
\text { Bandung } \\
\text { Regional } \\
\text { Ministry of } \\
\text { Education } \\
\text { Office. } \\
\text { Score: } 80\end{array}$ & $\begin{array}{l}\text { No significant } \\
\text { change in the } \\
\text { political climate } \\
\text { in Bandung, the } \\
\text { situation was } \\
\text { only heated up } \\
\text { in the scope of } \\
\text { the Bandung } \\
\text { Regional } \\
\text { Ministry of } \\
\text { Education } \\
\text { Office. } \\
\text { Score: } 80\end{array}$ & $\begin{array}{l}\text { No significant } \\
\text { change in the } \\
\text { political climate } \\
\text { in the city of } \\
\text { Bandung, the } \\
\text { conditions in the } \\
\text { Bandung } \\
\text { Regional } \\
\text { Ministry of } \\
\text { Education Office } \\
\text { was fine. } \\
\text { Score: } 90\end{array}$ \\
\hline
\end{tabular}




\section{b. Score Determination}

The existing criteria then reviewed in advance to see if it was included into the cost and benefit development before scaling process being done. Each criterion will give different meaning. Each criteria (economic, political and social culture) had the lowest score of 0 and 100 . The most disliked criteria scored 0 ; on the contrary, the most preferred criteria got a value of 100. [7]

c. Identifying Weight Rating Scenarios

In the weighting scenario rank, there are two stages: the weighting of the criteria and sub-criteria weighting. The weights of the criteria demonstrate management priority, while the weighting of sub-criteria indicates the level of importance of the sub criteria in the group criteria. By multiplying the priority rankings with a score of existing management in each of the criteria, when added together will produce the weight of the scenario. The results of policy evaluation with this method are the ranking scenario, so it can have the most desirable scenario.

d. Involving stakeholders' options in the preparation of rating the Policy Scenario

If the selection of stakeholder groups in the identification and analysis were different, it will then produce a priority which will change its ranking from previous scenarios. Stakeholder selection of different management priorities can be done in various ways. The information collected can form different data such as: nominal, ordinal, interval or ratio that is then converted into a ranking of each scenario.

\begin{tabular}{|c|c|c|c|c|}
\hline $\begin{array}{l}\text { Criteria } \\
\text { Sub-Criteria }\end{array}$ & Unit & $\begin{array}{c}\text { A } \\
\text { Scenario }\end{array}$ & $\begin{array}{c}\text { B } \\
\text { Scenario }\end{array}$ & $\begin{array}{c}\mathrm{C} \\
\text { Scenario }\end{array}$ \\
\hline \multicolumn{5}{|l|}{ Economy } \\
\hline $\begin{array}{l}\text { Time optimization \& } \\
\text { Human Resources } \\
\text { (HR) }\end{array}$ & Score & 20 & 50 & 90 \\
\hline Cost & Score & 30 & 30 & 90 \\
\hline \multicolumn{2}{|l|}{ Average Score } & 25 & 40 & 90 \\
\hline \multicolumn{5}{|l|}{ Social } \\
\hline $\begin{array}{l}\text { Society needs to have a } \\
\text { decent education }\end{array}$ & Score & 50 & 50 & 85 \\
\hline $\begin{array}{l}\text { Justice for all to get a } \\
\text { decent education }\end{array}$ & Score & 20 & 20 & 90 \\
\hline \multicolumn{2}{|l|}{ Average Score } & 35 & 35 & 87,5 \\
\hline \multicolumn{5}{|l|}{ Politics } \\
\hline $\begin{array}{l}\text { Political temperature } \\
\text { stability when the } \\
\text { policy } \\
\text { implemented }\end{array}$ & Score & 80 & 80 & 90 \\
\hline \multicolumn{2}{|l|}{ Average Score } & 80 & 80 & 90 \\
\hline \multicolumn{2}{|l|}{ Total Average Score } & 46.67 & 51.67 & 89.17 \\
\hline
\end{tabular}

Table 5 shows the impact of scenarios based on the criteria laid out in terms of the criteria of economic, social, cultural and political sub criteria taken from six (6) elaboration of criteria suggested by [9], namely the effectiveness, efficiency, adequacy, equity, responsiveness and feasibility and scoring is based on a standard calculation offered by [7] complete with the scenario's amount of weight.

\section{e. Appraisal}

As the final stage, there will be a comprehensive assessment of the existing scenarios. The performances of the various scenarios are compared, and then researcher communicates as a result form the conclusion of the study.

From Table 5 obtained information that the average overall score on Scenario A is 46.67. While Scenario B earned an average score of 51.67 and Scenario $C$ earned an average score of 89.17 . The highest average score is 100 [7]

\section{CONCLUSION}

Based on the data and information obtained from this study, researcher drew a conclusion that also functions as an answer to the question of research in the exposure in the following paragraphs.

The 2015 PPDB policy and governance systems implementation in Bandung assessed from the analysis of trade-off by applying stakeholder analysis and multi-criteria indicated that the key policy actor (External Stakeholders) made a mistake at the time of taking the decision to create new policy during the policy implementation. This raises new uproar among parents and prospective new students who feel what is decided is not fair. However, considering the parents and prospective students were the primary stakeholders (actors with low power) and proved that the turmoil did not affect the conditions of life of the society both economically, socially and politically, then this incident need only be the starting point of learning in the next PPDB process.

The lack of socialization policies both against the executor of policies especially to the persons affected by the policy, causing PPDB 2015 exercise less effective and cause chaos due to lack of understanding of both parties.

Product of good policy requires a strong commitment to implementation in order to be well implemented. Based on the interpretation of data and information in this study, the problems that arise when implementing the selection policy PPDB in Bandung in 2015 and 2016 would occur as a result of irregularities over the gap that was done by parties who are not responsible, either in the problem of making SKTM spurious, false Family Card, Tutoring who trade value, selling seats, and others. Pressure, political climate and the conditions at the time of PPDB 2015 that eventually forced the release of the policy in the policy that ultimately did cause problems, unrest and turmoil that is different from the process PPDB ever in Bandung. [10], [11], [12, [13].

Weak oversight of government officials authorized to issue a statement of poverty is also a road used by people who are not responsible. [14] [15].

From the multi-criteria analysis, it can be seen that by making the determination scenarios of the data obtained from the analysis of stakeholders, can yield a product rationalization policies that take into consideration economic, social and political order to avoid the risks of policy decisions that are not appropriate. From the analysis of multi-criteria that researchers do, Mayor Regulation No. 
610 year 2016 may be a revision and answers to problems that arise during the implementation of the PPDB in Bandung in the previous year.

\section{REFERENCES}

[1] Undang - Undang RI No. 20 Tahun 2003 tentang Sistem Pendidikan Nasional. [Online]:
[Onger http://sdm.data.kemdikbud.go.id/SNP/dokumen/undang-undang-no20-tentang-sisdiknas.pdf cited in 17 September 2015.

[2] Patton, Carl V. \& Sawicki, David S. (1993). Basic methods of policy analysis and planning. $2^{\text {nd }}$ Edition. Englewood Cliffs, New Jersey 07632: Prentice Hall.

[3] Rice, S. and J. Newman (eds.) 2010. Empirical and Experimental Methods in Cognitive/Functional Research. Conceptual Structure, Discourse, and Language Series. Stanford: CSLI.

[4] Creswell, John W. (2014). Research design qualitative, quantitative, and mixed methods approaches. $4^{\text {th }}$ edition. Sage Publications, Inc. Thousand Oaks, CA.

[5] Rudestam, K. E. \& Newton, R. R. (1992). Surviving your dissertation. London: Sage

[6] Kismartini. (2004). Analisis trade-off sebagai alat analisis kebijakan publik dalam "Dialogue" JIAKP, Vol. 1, No.3 pp. 402 - 416. [Online]: https://core.ac.uk/download/files/379/11704481.pdf cited in 29 July 2016.

[7] Brown, Katrina., Tompkins, Emma., \& Adger, W. Neil. (2001). Trade-off analysis for Participatory Coastal Zone Decision-Making. Norwich, UK: Overseas Development Group.

[8] Lembaga Administrasi Negara. (2015). Modul pelatihan analis kebijakan. Jakarta: LAN.

[9] Dunn, William N. (2008). Public policy analysis: an introduction. $4^{\text {th }}$ edition. New Jersey: Englewood Cliffs.

[10] Louis, Karen S. (2005). Knowledge producers and policymakers: kissing kin or squabbling siblings? dalam Bascia et al [Ed] International Handbook of Educational Policy pp. 219 - 238. Netherlands: Springer.

[11] Rosen, Lisa. (2009). Rhetoric and symbolic action in the policy process dalam Sykes, Schneider \& Plank [Ed] Handbook of Education Policy Research pp. 267 - 285. New York: Routledge.

[12] Stovall, David O. (2009). Race(ing), class(ing), and gender(ing) our work: critical race theory, critical race feminism, epistemology, and new directions in educational policy research dalam Sykes, Schneider \& Plank [Ed] Handbook of Education Policy Research pp. $258-266$. New York: Routledge

[13] Torres, Carlos A., \& Van Heertum, Richard. (2009). Education and domination: reforming policy and practice through critical theory dalam Sykes, Schneider \& Plank [Ed] Handbook of Education Policy Research pp. 221 - 239. New York: Routledge.

[14] Baker, Bruce D \& Green, Preston C (2009). Conceptions, measurement, and application of educational adequacy and equal educational opportunity dalam Sykes, Schneider \& Plank [Ed] Handbook of Education Policy Research pp 438 - 452. New York: Routledge.

[15] Plecki, Margaret L. \& Castaneda, Tino A. (2009). Whether and how money matters in k-12 education dalam Sykes, Schneider \& Plank [Ed] Handbook of Education Policy Research pp. $453-463$. New York: Routledge. 